\title{
Aerobic biological treatment of landfill leachate
}

\author{
R. J. Matthews, M. K. Winson \& J. Scullion \\ University of Wales Aberystwyth, Institute of Biological Sciences, \\ Penglais, Aberystwyth, UK
}

\begin{abstract}
There is an ongoing need to treat leachates from landfills using approaches that avoid expensive installation and operating costs. Faced with such a problem, Powys County Council (Wales, UK) developed a treatment system based on practical experience. Leachate was re-circulated through aeration towers containing a biofilm supported on plastic media before being polished in reed/filter beds.

Investigations were undertaken to evaluate the performance of these processes. Replicated model aeration towers (1/300 site scale) were used to establish treatment rates for pollutants in leachates of varying strengths; the effects of temperature and variations in pollutant concentrations were also evaluated. Data from these model experiments were corroborated with findings from pilot-scale plants (1/10 site scale) operating on landfill sites. Assessment of treatment performance was based on the degree of amelioration of standard chemical (ammoniacal-N and total organic carbon) parameters. A range of related parameters including nitrate, $\mathrm{pH}$ and redox potential were measured in support of these assessments.

Model system experiments indicated treatment rates at $15{ }^{\circ} \mathrm{C}(883-1895 \mathrm{mg}$ $\mathrm{NH}_{3}-\mathrm{N} \mathrm{m}^{-3} \mathrm{~h}^{-1} ; 347-1600 \mathrm{mg}$ TOC m $\mathrm{m}^{-3} \mathrm{~h}^{-1}$ ) that were similar across a wide range of leachate concentrations (37-1880 $\mathrm{mgl}^{-1}$ ammoniacal-N; 130-5315 mgl-1 COD). Marked changes in the concentration of leachates did not affect treatment efficiency following a short lag effect. Process rates roughly halved with each $5^{\circ} \mathrm{C}$ decrease in temperature below $15^{\circ} \mathrm{C}$, significant nitrification was maintained at temperatures of $0.5-1{ }^{\circ} \mathrm{C}$. High variability in treatment capacity was observed for individual plastic media. Treatment rates in pilot scale plants were slightly higher but broadly consistent with those obtained in model systems.

Keywords: leachate treatment, aerobic, temperature, leachate strength, biofilm.
\end{abstract}




\section{Introduction}

Long-term, cost effective treatment of polluting emissions from landfills is important [1]. As water percolates through wastes emplaced in a landfill it dissolves organic and inorganic components and decomposition products to produce a potentially polluting liquid leachate. It is only relatively recently that the treatment of leachate has started to receive the type of thorough investigation which has been normal practice for sewage and other industrial effluents [2].

The putrescible components in municipal solid waste (MSW) have the potential to generate highly polluting and toxic leachates as they degrade. This degradation progresses through a series of more or less well defined stages towards maturity and eventual stability [3]. Leachate composition varies between stages, being highly enriched with organic breakdown products initially, then acidic with elevated concentrations of metal, chloride, ammonium and phosphate ions [4], then with higher $\mathrm{pH}$ and gradually declining concentrations of ammoniacal-N and organic concentrations through the prolonged methanogenic phase. In practice, leachates will be generated by wastes at various stages of degradation on all but the older closed sites. The timescale for each of the degradation stages has been shown to vary considerably according to; the type and nature of the emplaced wastes [5], landfill management practices [6] and local environmental conditions [7].

The composition of aged MSW leachates is such that they may be both polluting [8] and toxic [9] capable of producing severe environmental impacts especially in vulnerable recipients such as aquifers and surface waters. These effects may include eutrophication or toxic effects on aquatic organisms resulting from ammonia, heavy metals or organic compounds. Ammoniacal-N concentrations often present more of a long-term problem, than the leaching of degradable organic substances such as volatile fatty acids [10].

Remediation of leachate has been achieved primarily by aerobic biological treatment [11]. Although these technologies have developed in operational complexity to enhance the rate or extent of the biological conversions taking place [12], the fundamental biological reactions have remained essentially the same [13]. For leachates containing high concentrations of BOD, treatment processes (aerated lagoons, sequencing batch reactors, activated sludge) operating with flocculated heterotrophic micro-organisms in suspension and the assimilation of ammoniacal-N into biomass, have been widely reported [14]. For methanogenic leachates, nitrification utilising autotrophic, fixed microbial film processes (biofilm towers, trickling biofilters, rotating biological contractors) have been shown to be generally effective in reducing ammoniacal-N concentrations [15].

This study examines the effectiveness of a leachate treatment technology developed for former MSW landfill sites managed by Powys CC in Mid Wales, UK. Previous on-site investigations [16] indicated that leachate treatment was achieved primarily within aeration towers, so this treatment stage became the focus of more detailed study using replicated 'model' systems and pilot scale systems for on-site validation of findings. 


\section{Materials and methods}

Replicated model systems (1/300 of typical site scale) of aeration towers filled with plastic media (Mass Transfer Cascade Filterpak TM Stoke, UK) were used to establish treatment rates for leachates of varying strengths (see Figure 1 for schematic) operating under different temperature regimes.

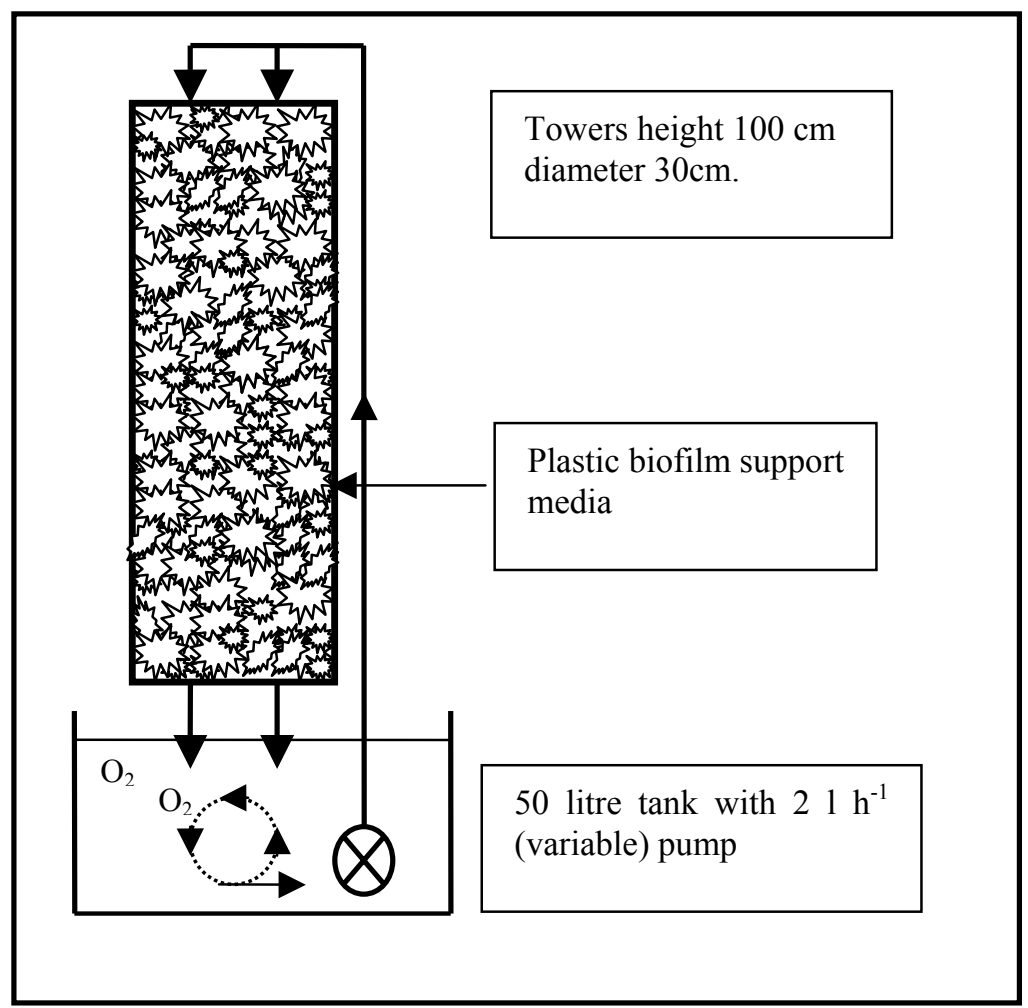

Figure 1: Schematic of model system experimental set-up.

Data reported are for a series of experiments using leachates from three landfill sites with widely varying characteristics (Table 1); Nantycaws 2 and Trecatti were operational. For practical reasons, experiments involved treating leachate in batches to completion. Experiments typically included 3-4 replicates depending on the number of treatment comparisons. Findings from these model experiments were corroborated with data from pilot-scale plants $(1 / 10$ of typical site scale).

Leachates were treated in temperature controlled growth rooms (4 replicates) at temperatures of $0.5-1,10,15$ and $30{ }^{\circ} \mathrm{C}$; the first three temperatures were chosen to represent the predominant range under UK conditions whilst the highest temperature may represent close to 'optimum' conditions for nitrification 
[17]. Data presented here are for one site (Borth) only; data comparing treatment rates for different leachates are for Borth, Nantycaws $1 \& 2$ and Trecatti leachate at $15{ }^{\circ} \mathrm{C}$. Air and leachate temperatures were routinely monitored during pilot plant trials; for the data presented, mean leachate temperatures were $11,16.5,13$ and $16.1{ }^{\circ} \mathrm{C}$ for Borth, Nantycaws 1, Nantycaws 2 and Trecatti respectively. Repeat runs were treated as replicates for the pilot plant.

Table 1: $\quad$ Typical characteristics of landfill leachates included in studies.

\begin{tabular}{|l|c|c|c|c|c|}
\hline Site & $\mathrm{pH}$ & $\begin{array}{c}\mathrm{NH}_{4}-\mathrm{N} \\
\mathrm{mgl}^{-1}\end{array}$ & $\begin{array}{c}\text { Total Fe } \\
\mathrm{mgl}^{-1}\end{array}$ & $\begin{array}{c}\mathrm{COD} \\
\mathrm{mgl}^{-1}\end{array}$ & $\begin{array}{c}\mathrm{BOD} \\
\mathrm{mgl}^{-1}\end{array}$ \\
\hline Borth & 7.5 & 177 & 10.3 & 137 & 42 \\
\hline Nantycaws 1 & 7.7 & 37 & 0.5 & 131 & 22 \\
\hline Nantycaws 2 & 8.1 & 1880 & 2.1 & 5315 & 639 \\
\hline Trecatti & 7.9 & 1195 & 3.4 & 1575 & 124 \\
\hline
\end{tabular}

Treatment rates were routinely recorded following changes in leachate concentration or composition to identify any differences in treatment rate resulting from variations in the prior history of individual model towers. Data are presented for one occasion where intensive monitoring was undertaken. Replicate towers were exposed to full strength (130 $\mathrm{mg} \mathrm{l}^{-1}$ ammoniacal-N) or fully treated $\left(<1 \mathrm{mg} \mathrm{l}^{-1}\right.$ ammoniacal-N) Borth leachate for several days, then all towers were switched to full strength Borth leachate and changes in ammoniacal$\mathrm{N}$ recorded over the subsequent days treatment completion.

Individual media elements were investigated to determine the degree of heterogeneity in nitrification potentials within the model systems. These were submerged in solutions of $20 \mathrm{mgl}^{-1}$ ammoniacal-N ( $\mathrm{pH} \mathrm{6.3)} \mathrm{and} \mathrm{placed} \mathrm{on} \mathrm{orbital}$ shakers $\left(20{ }^{\circ} \mathrm{C}\right)$. Ammoniacal-N concentrations were measured initially and twice daily until treatment completion.

Ammoniacal-N was determined [18] using a Cecil Series 2 spectrophotometer measuring absorbance at $630 \mathrm{~nm}$. Nitrate was determined by anion exchange chromatography (Dionex QIC Ion Chromatograph); samples were filtered $(<0.2 \mu \mathrm{m})$ prior to injection. Total organic carbon was measured using a Shimadzu analyser (TOC-5050). The $\mathrm{pH}$ and $\mathrm{Eh}$ of samples were determined routinely using Hanna (301) meters. Dissolved oxygen concentrations were recorded using a Jenway (970) oxygen meter.

Treatment rates were determined by fitting linear regressions to changes in concentrations with time for individual replicate towers. Rates were then recalculated as $\mathrm{mg} \mathrm{m}^{-3}$ media $\mathrm{h}^{-1}$. Most experiments, involved in excess of 10 sampling occasions with sampling intervals varied according to the period of the experimental run as affected by leachate strength. There was no evidence of these rates being affected by substrate concentrations except when treatment approached completion as illustrated in Figure 2 ; regression $\mathrm{R}^{2}$ values were consistently $>90$ and usually $>95 \%$. Mean process rates were then compared by one-way analysis of variance. 


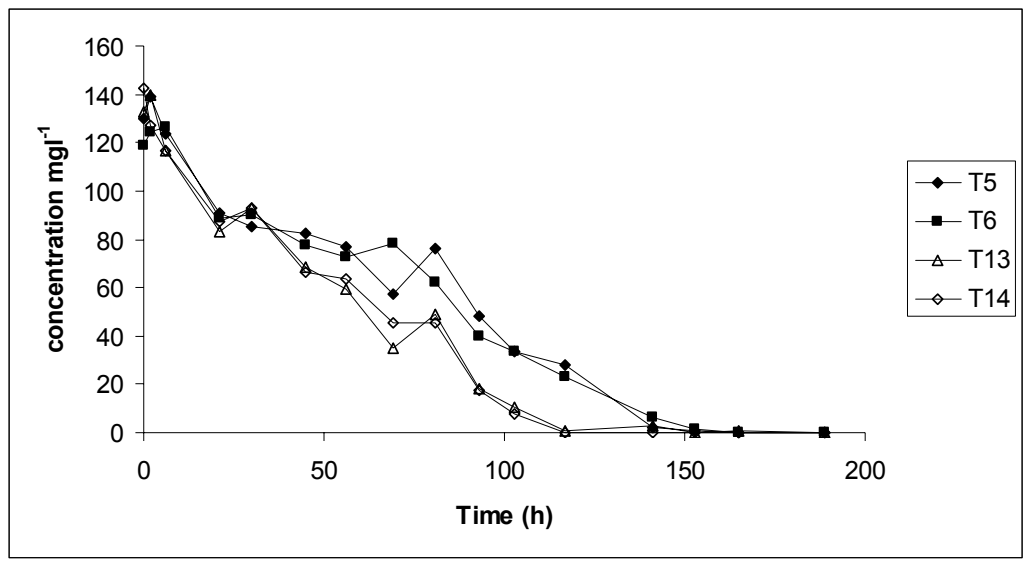

Figure 2: Linear reductions in ammoniacal-N concentration (Borth leachate) for 4 replicate model tower systems.

\section{Results}

Effects of varying temperature on treatment of the Borth leachate are described in Table 2. Nitrification rates and nitrate-N production rates broadly corresponded when ammonification of organic- $\mathrm{N}$ is taken into account. Between $0.5{ }^{\circ} \mathrm{C}$ and $15{ }^{\circ} \mathrm{C}$ process rates roughly doubled for each $5{ }^{\circ} \mathrm{C}$ temperature increment, with rates at $15{ }^{\circ} \mathrm{C}$ roughly a third of the optimum $30{ }^{\circ} \mathrm{C}$ rates. Significant amelioration of leachate was maintained even at temperatures close to freezing point. For this leachate, $\mathrm{pH}$ remained above 7.5 throughout the treatment period; apart from the initial 2 hour period when dissolved oxygen concentrations and redox potentials were low, these parameters stabilised in excess of $7 \mathrm{mg} \mathrm{l}^{-1}$ and $170 \mathrm{mV}$ respectively for most of the remaining period.

Table 2: Effects of varying temperature on process rates $\left(\mathrm{mg} \mathrm{m}^{-3} \mathrm{~h}^{-1}\right)$ for Borth leachate; a) ammoniacal-N, b) nitrate-N and c) organic carbon.

a)

\begin{tabular}{|l|c|c|c|c|}
\hline \multicolumn{1}{|r|}{ Temperature $^{\circ} \mathrm{C}$} & 0.5 & 10 & 15 & 30 \\
\hline Mean & 200 & 469 & 861 & 3109 \\
\hline Standard deviation & 30.3 & 119.8 & 133.9 & 94.7 \\
\hline
\end{tabular}

b)

\begin{tabular}{|l|c|c|c|c|}
\hline \multicolumn{1}{|c|}{ Temperature ${ }^{\circ} \mathrm{C}$} & 0.5 & 10 & 15 & 30 \\
\hline Mean & 169 & 505 & 765 & 3353 \\
\hline Standard deviation & 42.0 & 142.8 & 119.0 & 236.6 \\
\hline
\end{tabular}

c)

\begin{tabular}{|l|c|c|c|c|}
\hline \multicolumn{1}{|r|}{ Temperature $^{\circ} \mathrm{C}$} & 0.5 & 10 & 15 & 30 \\
\hline Mean & 408 & 1097 & 1600 & 4343 \\
\hline Standard deviation & 18.9 & 290 & 123.5 & 611.8 \\
\hline
\end{tabular}


Comparisons of process rates for different leachates at $15{ }^{\circ} \mathrm{C}$ are presented in Table 3. Ammoniacal-N concentrations decreased more rapidly for the stronger leachates, particularly Nantycaws 2 . This difference was not reflected in nitrate production rates. Ammonia volatilisation detected for the Nantycaws 2 leachate could not fully explain this discrepancy; denitrification was detected and this occurrence was consistent with low Eh values (c. $100 \mathrm{mV}$ ) for much of the early treatment of this leachate. Organic $\mathrm{C}$ treatment rates for the Nantycaws 1 leachate, which had low initial OC, were notably lower than for other leachates. Values for the two operational sites were intermediate and highly variable

Table 3: Process rates at $15{ }^{\circ} \mathrm{C}$ constant temperature $\left(\mathrm{mg} \mathrm{m} \mathrm{m}^{-3} \mathrm{~h}^{-1}\right)$ for a) ammoniacal-N, b) nitrate-N and c) organic carbon for model systems.

a)

\begin{tabular}{|l|c|c|c|c|}
\hline Leachate & Borth & Nantycaws 1 & Nantycaws 2 & Trecatti \\
\hline Mean & 968 & 883 & 1895 & 1335 \\
\hline Standard deviation & 123.5 & 327.9 & 242.7 & 97.7 \\
\hline
\end{tabular}

b)

\begin{tabular}{|l|c|c|c|c|}
\hline Leachate & Borth & Nantycaws 1 & Nantycaws 2 & Trecatti \\
\hline Mean & 861 & 1191 & 982 & 1095 \\
\hline Standard deviation & 133.9 & 266.6 & 617.1 & 529.7 \\
\hline
\end{tabular}

c)

\begin{tabular}{|l|c|c|c|c|}
\hline Leachate & Borth & Nantycaws 1 & Nantycaws 2 & Trecatti \\
\hline Mean & 1600 & 347 & 1304 & 1024 \\
\hline Standard deviation & 123.5 & 136.0 & 635.5 & 415.8 \\
\hline
\end{tabular}

Table 4: Process rates at variable temperature $\left(\mathrm{mg} \mathrm{m}^{-3} \mathrm{~h}^{-1}\right)$ for a) ammoniacal-N, b) nitrate- $\mathrm{N}$ and c) organic carbon for pilot plant systems.

a)

\begin{tabular}{|l|c|c|c|c|}
\hline Leachate & Borth & Nantycaws 1 & Nantycaws 2 & Trecatti \\
\hline Mean & 2428 & 2184 & 2333 & 2181 \\
\hline Standard deviation & 4.8 & 422.7 & 57.7 & 508.6 \\
\hline
\end{tabular}

b)

\begin{tabular}{|l|c|c|c|c|}
\hline Leachate & Borth & Nantycaws 1 & Nantycaws 2 & Trecatti \\
\hline Mean & 1636 & 2651 & 1656 & 1050 \\
\hline Standard deviation & 221.2 & 72.7 & 7.8 & 378.2 \\
\hline
\end{tabular}

c)

\begin{tabular}{|l|c|c|c|c|}
\hline Leachate & Borth & Nantycaws 1 & Nantycaws 2 & Trecatti \\
\hline Mean & 2582 & 3404 & 1254 & 354 \\
\hline Standard deviation & 455.2 & 1318 & 619.3 & 137.7 \\
\hline
\end{tabular}

Batches of leachate were treated in pilot plants on each of the landfill sites (Table 4). In making comparisons between model and pilot plant systems differences in temperature and general environmental conditions must be considered. Rates of ammoniacal-N reduction and nitrate- $\mathrm{N}$ production were 
generally comparable and broadly consistent with data from model systems with the exception of the very high OC values for Nantycaws 1 .

Nitrification capacity (Figure 3) was highly variable between individual media and there was some evidence of a trend towards a reduction in this capacity with depth in the model system towers.

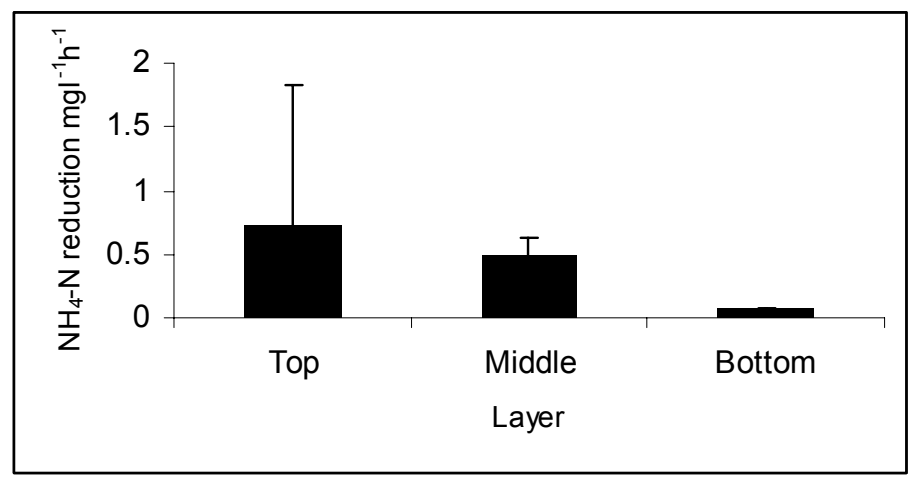

Figure 3: Reductions in ammoniacal-N concentrations for individual media (6 reps) in standard solutions for 3 days (error bars $=$ standard deviations).

Treatment rates were affected (Table 5) by the nature of the preceding leachate to which model systems were exposed. Towers with low strength leachate treated ammoniacal- $\mathrm{N}$ at rates about two thirds those of towers treating stronger leachate; this difference was not apparent beyond the first day of the trial.

Table 5: Reduction in ammoniacal-N after 1 and $15 \mathrm{~h}$ as affected by previously treated leachate $\left(\mathrm{H}=130\right.$ and $\mathrm{L}=<1 \mathrm{mg} \mathrm{l}^{-1}$ ammoniacal-N).

\begin{tabular}{|c|c|c|c|c|}
\hline Previous leachate & $\mathrm{H}$ & $\mathrm{L}$ & $\mathrm{H}$ & $\mathrm{L}$ \\
\hline Time $(\mathrm{h})$ & 1 & 1 & 15 & 15 \\
\hline Mean $\mathrm{mg} \mathrm{l}^{-1}$ & 9.8 & 6.3 & 96.1 & 66.9 \\
\hline Standard deviation & 5.26 & 5.12 & 5.70 & 24.14 \\
\hline
\end{tabular}

\section{Discussion}

Work undertaken by Tschui et al. [19] has shown the specific growth rates of nitrifying bacteria are extremely slow compared with those of heterotrophic bacteria, necessitating the lowering of organic loading rates to reduce the competition between heterotrophic and autotrophic bacteria [20]. Our results 
indicate that heterotrophic and nitrifying bacteria can co-exist within this treatment system at least across the range of leachates tested.

Nitrification has been demonstrated in soil close to $0{ }^{\circ} \mathrm{C}[21]$. Kettunen et al. [22] have reported ammoniacal-N removal rates of between $65-99 \%$ respectively at process residence times of 2.7 and 4.2 days, for aerobic leachate biotreatments at temperatures within the range $1-5^{\circ} \mathrm{C}$. Nitrification occurs optimally within the range $25-35{ }^{\circ} \mathrm{C}$ [17]. Findings reported here indicate process rates at $0.5{ }^{\circ} \mathrm{C} 7,5$ and $9 \%$ those of optimum values for ammoniacal-N, nitrate- $\mathrm{N}$ and organic carbon respectively. In the UK where the majority of leachate production is concentrated during the winter months, data for optimum temperatures are often unrealistically high [11]. Based on laboratory scale experiments the effects of temperature on the rate of nitrification have been estimated at $12 \%{ }^{\circ} \mathrm{C}^{-1}$ within the temperature range $7-20^{\circ} \mathrm{C}$ [23]. Our results are again broadly consistent with these general findings.

Nitrification requires a significant amount of oxygen $\left(4.33 \mathrm{~g} \mathrm{O}_{2}\right.$ per gram of $\mathrm{NH}_{4}-\mathrm{N}$ ) [24]. The natural passage of air through voids present in the biofilm support media [25] has been shown to avoid oxygen limitation and in our trials dissolved oxygen concentrations in bulk leachate were maintained close to saturation even for the strongest leachates.

The oxidation of free ammonia to nitrite consumes two moles of alkalinity per mole of ammonia oxidised [26] and may result in acidification. Acidic $\mathrm{pH}$ in poorly buffered leachates reduces the concentration of free ammonia and may also inhibit oxidation by reducing the specific growth rate of the bacteria [27]. Although the optimal $\mathrm{pH}$ required for nitrification has been estimated at 8.5 [28], our experiments indicate sustained rates of nitrification at $\mathrm{pH}$ 's $<7.00$ although treatment stalling was observed at variable $\mathrm{pH}$ 's below this value.

It has also been suggested that ammonia may inhibit nitrite oxidation by Nitrobacter bacteria. However, more recent studies [27] have however shown that significant variability exists in the degree of inhibition. Ammonia present in high concentrations has also been reported to inhibit its own oxidation by Nitrosomonas bacteria but again the degree of inhibition is variable [14] and may be influenced by temperature and $\mathrm{pH}$ [29]. There was no evidence of any such inhibition across the range of ammoniacal-N concentrations and $\mathrm{pH}$ ranges tested in the trials reported here.

Although there was some evidence of delayed response to marked changes in leachate concentration, the treatment system evaluated proved to be robust both at model and pilot scales across a very wide range of leachate characteristics encompassing long closed to fully operational sites. Clearly there is high spatial and perhaps temporal variability in process capacity within the tower media. Some degree of variability is inevitable but there may be scope for further improvements in treatment rates if some of this variability could be avoided.

\section{Acknowledgements}

This work was jointly funded by Biffaward and Biffa Waste. 


\section{References}

[1] Haarstad, K. \& Mæhlum, T., Important aspects of long-term production and treatment of municipal solid waste leachate. Waste Management and Research 17, pp. 470-477, 1999.

[2] Williams, P.T., Waste Treatment and Disposal. John Wiley \& Sons Ltd, West Sussex, England, 1999.

[3] Heyer, K.U. \& Stegmann, R. 1997. The long-term behaviour of landfills: Results of the joint research project Landfill Body. Sardinia, $6^{\text {th }}$ International Landfill Symposium, Conference Proceedings, CISA, Caliari, Italy, Vol. 1, pp. 73-87.

[4] Zweifel, H.R., Johnson, C.A. \& Holm, E., Long-term analyses of the main leachate constituents from old disposal sites. Müll und Abfall, 31, pp. 727732, 1999.

[5] Department of the Environment (DoE), A review of the composition of leachates from domestic wastes in landfill sites. Report No. CWM 072/94. In: Waste Management Paper 26B. Landfill Design, Construction and Operational Practice. HMSO, London, 1995.

[6] Hjelmar, O., Johannessen, L.M., Knox, K., Ehrig, H.J., Flyvbjetg, J., Winther, P. \& Christensen, T.J., The composition and management of leachate from landfills within the EU. In: Christensen, T.J., Cossu, R. and Stegmann, R. (Eds.) The $5^{\text {th }}$ International Landfill Symposium. CISA, Environmental Sanitary Engineering Centre, Cagliari, 1995

[7] Blight, G.E. \& Fourie, A.B. 1999 Leachate generation in landfills in semi arid climates. Geotechnical Engineering 137, pp. 181-188.

[8] Gray, D.A., Mather, J.D. \& Harrison, I.B., A review of groundwater pollution from waste disposal sites in England and Wales, with provisional guidelines for future site selection. Quarterly Journal of Engineering Geology 7, pp. 181-186, 1974.

[9] Osborn, D., Malcom, H.M., Wright, J., Freestone, P., Wyatt, C. \& French, M.C., Assessment of the role of landfill operations in the contamination of wildlife by organic and inorganic substances. National Groundwater and Contaminated Land Centre (EA). Report CWM 102/94. 1994.

[10] Harrington, D.W. \& Maris, P.J., The treatment of leachate: A UK perspective. Water Pollution and Control 20, pp.45-55, 1986.

[11] Robinson, H.D. \& Barr, M.J., Aerobic biological treatment of landfill leachates. Waste Management and Research 17, pp. 478-486, 1999.

[12] Robinson, H.D. The UK: leading the way in leachate treatment. Proceedings of the Institute of Waste Management (IWM) 12, pp 4-10, 1996.

[13] Britz, T.J. Landfill leachate treatment. In: Senior, E. (Ed.) The Microbiology of Landfill Sites, $2^{\text {nd }}$ Ed. CRC Press, Boca Raton, Florida, USA, 1995.

[14] Butler, P.R., Kitchin, J.E., Parry, C. \& Lane, P.G. Characterisation of a sequencing batch activated sludge process for treatment of high ammonia landfill leachates. Proceedings Institute of Wastes Management, March, pp. 9-18, 1999. 
[15] Knox, K., Leachate treatment with nitrification of ammonia. Water Research, 19, pp. 895-904, 1985.

[16] Matthews, R.J. Field and laboratory investigations of biological landfill leachate schemes in Wales. MSc thesis, University of Wales, Aberystwyth, 2001.

[17] Bock, B.R. Efficient use of nitrogen in cropping systems. In: Nitrogen in Crop Production. Hauck, R.D. (Ed.) American Society of Agronomy, pp. 273-294, 1984.

[18] Harwood J.E \& Kühn, A.L. A colorimetric method for ammonia in natural waters, Water Research 4, pp. 805-811, 1970.

[19] Tschui, M., Boller, M., Gujer, W., Eugster, J., Mader, C. \& Stengel, C., Tertiary nitrifcation in aerated pilot biofilters. Water Science and Technology 29, pp. 109-116, 1994.

[20] Boller, M., Gujer, W. \& Tschui, M., Parameters affecting nitrifying biofilm reactors. Water Science and Technology 29, pp. 1-11, 1994.

[21] Schmidt, E.L. Nitrification in soil, In: Nitrogen in Agricultural Soils. Stevenson, F.J. (Ed.) American Society of Agronomy, Crop Science of America, Soil Science Society America, Madison, Wisconsin, USA, pp. 253-288, 1982.

[22] Kettunen, R.H., Keskitalo, P., Hoilijoki, T.H. \& Rintala, J.A., Biological treatment for removal of organic material and ammonium from leachate at low temperatures. Waste Management and Research 17, pp. 487-49, 2000.

[23] Pelkonen, M., Kotro, M. \& Rintala, J., Biological nitrogen removal from landfill leachate: a pilot scale study. Waste Management and Research 17, pp. 493-497, 1999.

[24] Gujer, W. \& Boller, M., Operating experience with plastic media tertiary trickling filters for nitrification. Water Science and Technology 16, pp. 201-213, 1986.

[25] Daigger, G.T., Heinemann, T.A., Land, G. \& Watson, R.S., Practical experience with combined carbon oxidation and nitrification in plastic media trickling filters. Water Science and Technology 29, pp. 189-196, 1994.

[26] Fisher, M. \& Fell, C., Ammonia removal from high strength leachate using a sequencing batch reactor. Wastes Management, March, pp 25-26, 1999.

[27] Hunik, J.H., Meijer, H.J.G. \& Tramper, J., Kinetics of Nitrosomonas europea at extreme substrate product and salt concentrations. Applied and Environmental Microbiology 37, pp. 802-807, 1992.

[28] U.S. Environmental Protection Agency (EPA) Technology Transfer. Process Design Manual for Nitrogen Control, Washington D.C., USA, 1975.

[29] Kim, D.J., Lee, D.I. \& Keller, J., Effect of temperature and free ammonia on nitrification and nitrite accumulation in landfill leachate and analysis of its nitrifying bacterial community by FISH. Bioresource Technology 97, pp 459-468, 2006. 